UDC 75.071.1:929 Nešković N.

https://doi.org/10.18485/ms_zmslu.2021.49.5

Оригинални научни рад

Милена Г. Врбашки*

\title{
КО ЈЕ НА АУТОПОРТРЕТУ НИКОЛЕ НЕШКОВИЋА: РЕИДЕНТИФИКАЦИЈА АУТОРА, ПИТАЊА И НЕКИ ОДГОВОРИ
}

САЖЕТАК: Иконично дело о чијој атрибуцији се расправља у тексту уведено је у

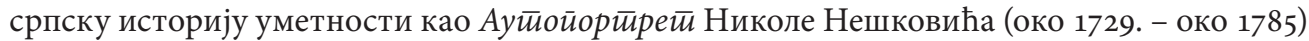

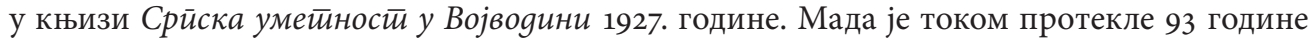

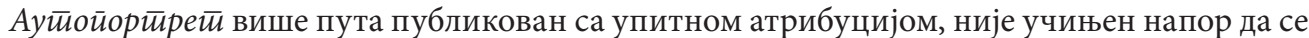
теза о Нешковићевом ауторству оповргне. Полазна тачка за проналажење вероватнијег аутора био је проналазак друге потписане слике скоро сасвим непознатог сликара, Василија Недељковића (1759/1760-1796), који је био родбински повезан са Николом Нешковићем (његов зет, ожењен његовом ћерком Јулијаном). Пре ове друге, било је познато само Недељковићево Расйеће (1792), чији су уметнички квалитети високо оцењени у лите-

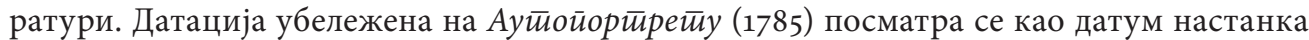
дела, а не повезује се са годином Нешковићеве смрти која је, према досадашњим непо-

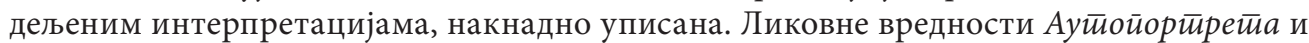
сигурних, потписаних радова пружиле су основ за друкчије посматрање још неколико непотписаних дела која имају исто порекло, или се на други начин могу уврстити у Недељковићев хипотетични опус. Поред хипотеза, у тексту се наводи податак о претходно непознатом датуму Недељковићеве смрти, који представља оријентир за могућу уметникову биографију.

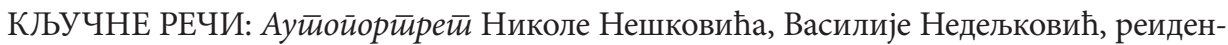

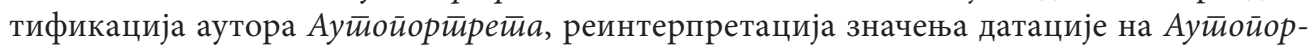
$\bar{u} p e \bar{u} y(1785)$, кохеренција представе и датума као визуелни основ за реатрибуцију

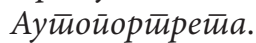

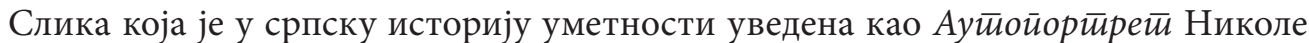
Нешковића и од тада публикована углавном са несумњивом атрибуцијом, појавила се у стручној литератури у књизи Срйска умейносй у Војвоgини 1927. године (ПЕтровит 1927), делу које је и дан-данас често полазна тачка за истраживаче националне уметности. О овом иконичном портрету домаћег сликарства написано је следеће:

* Галерија Матице српске, Нови Сад, m.vrbaski@galerijamaticesrpske.rs 
Г. Вујић је нашао у Вршцу Нешковићев Ауйойорйре, који, ако је његов, биће опет један драгоцен прилог за познавање тог значајног века и наше националне психе. На том Аутопортрету наш сликар је приказан у помодном оделу XVIII века, à la Goethe, c чипкастом пошом, с љубичастим прсником, с фином кичицом у десној, грациозној руци и с палетом у левој, пред разапетим платном. Облик и израз лица веома културан и интелигентан. Слика је добра, али она нама још више значи од једног нашег коректно маланог портрета, јер нам говори о томе како је Србин способан био и пре двеста година за невероватну брзу метаморфозу (Петровић 1927: 76).

Из прве реченице цитираног текста сазнајемо да је слику „нашао” Јован (Јоца) Вујић (1863-1934), познати колекционар, оснивач и власник музеја у Сенти, те уочавамо да Вељко Петровић (1927: 76) уноси одређену резерву у погледу Нешковићевог ауторства, односно идентитета портретисаног. У наставку текста, међутим, дело се разматра као несумњиво Нешковићево:

Овај отмени господин и салонски артист, потпуно сличан таквима по престоницама од Беча до Лондона, још пре неких десет година трчкарао је с фесићем и турићем по једној турској чаршији [...] Његов унук Јован Сӣерија Пойовић је [...] забележио да је Нешковић и као грађанин заузимао угледно место у друштву и да се бавио и књижевношћу, дидактичким стиховима, у духу тадашњег времена. Умро је 1785. године (ПЕТРОВИЋ 1927: 76-77).

Година која се наводи, 1785, уписана је на слици, а из белешке колекционара Вујића у рукописном инвентару његове збирке, која се у стручној литератури прихвата као несумњива, изведена је теза да је Нешковић те године преминуо:

Нешковић Никола дед по матери Ј. Стерије Поповића рођен у Пожаревцу, умро у Вршцу.

170. Аутопортре. Платно. Висина $68 \mathrm{~cm}$. Ширина $54 \mathrm{~cm}$. Слика је од прилике из доба око 1760 г. Боја године је много беља, друге беле боје су пожутеле. Зато мислим, да је то година смрти. Sign. Десно око среде: $1785 \Lambda$ БТО. /: По свој прилици година смрти.

Нешковић Никола

Добио на поклон од Гђе Петровићке у Вршцу 1924. г. Гђе Петровићкин муж беше нећак Јов. Стерије Поповића. ${ }^{1}$ (сл. 1).

Јоца Вујић је ову слику поклонио Београдском универзитету, заједно са другим

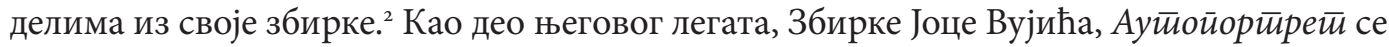
чува у Народном музеју у Београду и излаже у његовој сталној поставци. Ауторству портрета није приступано довољно критички, мада се у стручној литератури иза

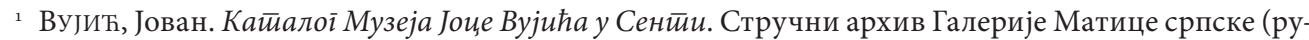
копис, фотокопија). Текст је наведен дословно, без икаквих интервенција.

2 Шелмић, КУСОВАЦ и др.: 1989. Детаљније о поклону Јоце Вујића Београдском универзитету: ФилИПОВИЋ, МАРКОВИЋ 2012. 


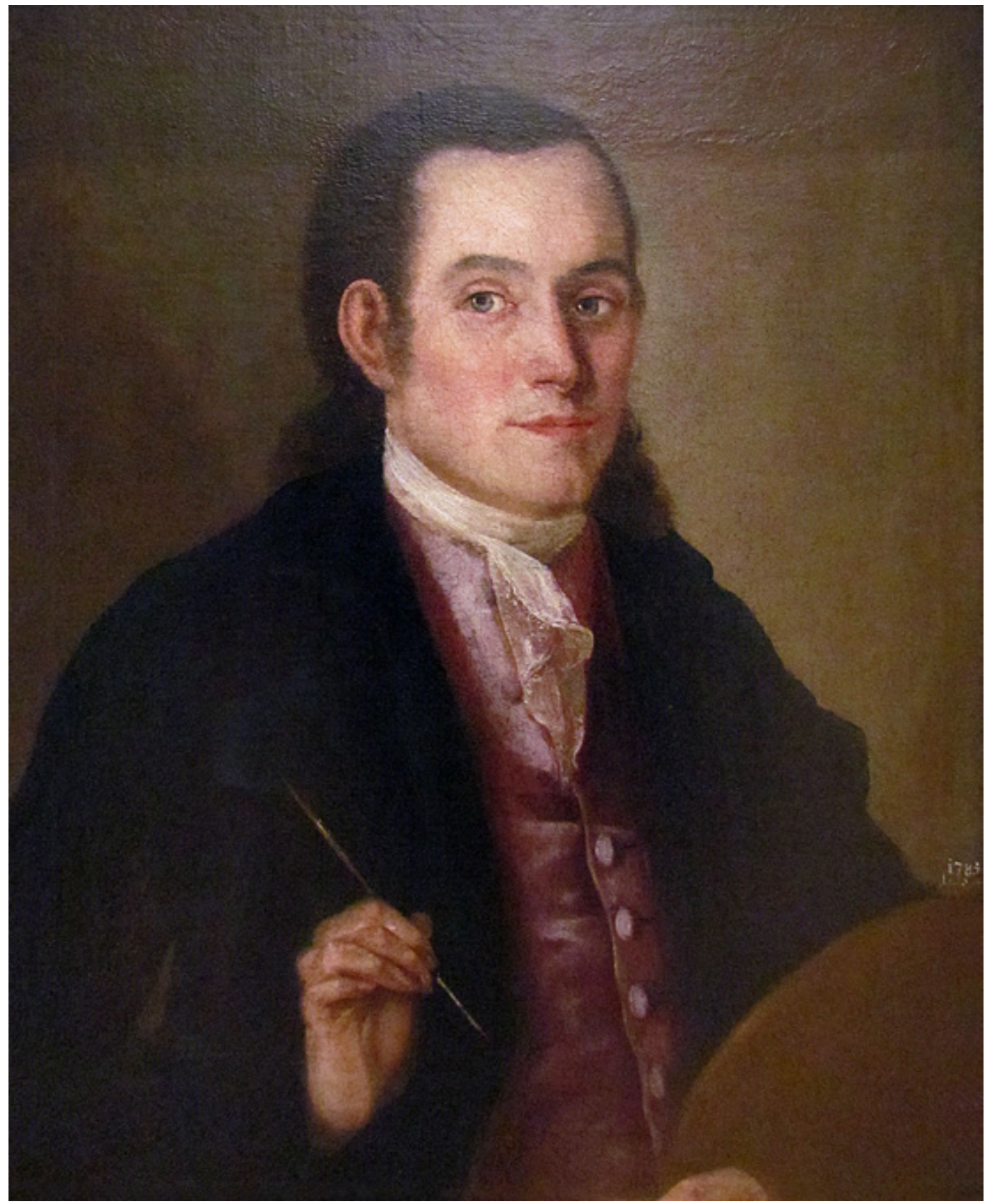

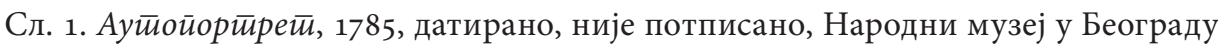
(фото: Народни музеј, Београд) 


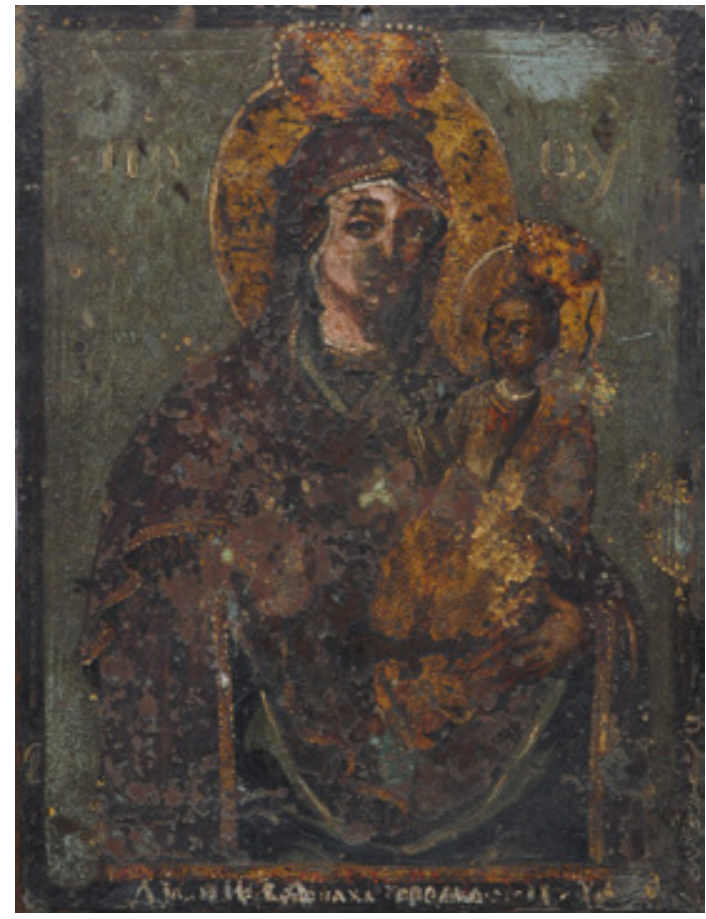

Сл. 2. Боїороgица са Хрисйом, 1785, потписано и датирано, Галерија Матице српске (фото: Галерија Матице српске, Нови Сад) имена Нешковића као аутора на више места налазе упитници. С обзиром на то да се године у којима је Нешковић (рођен је у Пожаревцу око 1729) не слажу са годинама у којима је приказана особа на слици, пласирана је теза да је портрет настао око 1760, а да се уписана година односи на годину Нешковићеве смрти (сл. 2).

Повод да посумњам у ауторство Ауйойорйрейа искрснуо је 2007. године, када је Галерији Матице српске на откуп понуђена мала икона Боі̄opoguиа са Хрисйом, на чијој полеђини се налази двореди запис о њеној обнови. ${ }^{4}$ Пре него што је откуп реализован, замолила сам власника да дозволи да конзерватори очисте доњу ивицу лица иконице, на којој ми се учинило да постоји текст. Чишћењем је откривено да се испод горњег слоја налази потпис аутора: „азъ Васил1е Неделковїчъ Малеръ: 1785. гшд." С обзиром на то да ми је Недељковић као аутор био непознат, у моменту откупа његове иконе за збирку Галерије најпре сам пронашла информативну биографску јединицу (MeDAKović 1964: 537) која је упућивала на једини стручни чланак Ивана Баха (ВАсн 1949) о његовом првом, и до откупа иконе Боїороguияа са Хрисӣом, једином потписаном делу, икони Расиеєће која се чува у Српској православној црквеној општини у Загребу. Расйеће се као једино познато дело наводи и у енциклопедијском издању аутора Бранислава Тодића Срйски сликари og XIV go XVIII века (2013а: 91), у којем је

3 Скорашња конзерваторско-рестаураторска интервенција открила је да се испод ове налази још једна ситнија делимично читљива датација: $1[.]$.5 лёто [Х.....]. Захваљујем конзерватору Наташи Илић из Народног музеја у Београду на фотографији и увиду у рукопис о конзерваторско-рестаураторском

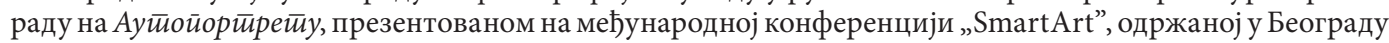
2019. у организацији Факултета примењених уметности.

4 Запис гласи: „обновыа азъ грбшнїи рабъ|Хрїстшфоръ Петровичъ”. У Галерији Матице српске се налази још једна икона истог аутора која показује различите стилске одлике. О сликару Христифору (Храниславу) Петровићу сачувани су само оскудни подаци. Био је јерођакон манастира Шишатовца (навео у запису на икони Св. Николе из 1842, ГМС/У 1926: „сей Образ моловалъ Хранислав Петровичъ | іеродіаконъ Шишатовачкій льта 842"). Сликарски је активан у Срему у првој половини и средином XIX века. Слика према ретардираним формулама, „још у светогорским традицијама” (KoLARIĆ 1964: 665).

5 ВАСн 1949: 185-209. О Недељковићевој икони 207-208, са црно-белом репродукцијом. 
у скорашње време дата најпотпунија Недељковићева биографија. Уз биографију су наведене комплетна литература и архивска грађа коју је аутор користио, са подацима о Недељковићевим мање важним, позлатарским и разним фарбарским пословима за цркве. Најдрагоценији податак односи се на претпостављену, претходно непознату годину његове смрти, када је „Јулијана, молера Васе йочивщаі̄o суйруїа приложила [...] 20. септембра 1797. две форинте за израду иконостаса у вршачкој Саборној цркви" (Тодић 2013а: 91). Тодић такође понавља претходно познати податак да је Недељковић био ожењен Нешковићевом ћерком, наводећи да је са њом имао двоје деце, од којих је млађе, Павле, крштен 20. октобра 1795. Из биографије Николе Нешковића у истој књизи (2013б: 62) сазнајемо да је Јулијана крштена 12. фебруара 1770. у Саборној цркви и да се после ране смрти сликара Василија Недељковића преудала за трговца Стерију Поповића. 6 Датум Јулијаниног крштења је драгоцен, с обзиром на то да су се деца крстила обично дан након рођења. На основу овог датума оквирно сам претпоставила године њеног првог супруга Василија Недељковића, који је од ње био старији најмање 3 до 5, а с обзиром на то да се радило о првом браку, највише 10 година.? Накнадно, у току рада на довршењу овог текста, пронађени су веродостојни подаци о Недељковићу који потврђују изнету претпоставку. У књизи умрлих Саборне вршачке цркве, под датумом 29. мај 1796. уписано је:

Престависја раб божји Василиј Недељков малер житељ места Вершца, коториј поживе 36 лет прежде исповедавшисја и причавстишсја, погребен бист при Цркве храма спаситеља и чудотворца Николаја чрез мене Никанора Нешича пароха. ${ }^{8}$ (сл. 3).

6 Према подацима са електронског портала Е-Вршац („еvrsac” Аноним), одељак с насловом „Стерија и Јулијана Поповић”, Јулијана се 7. II 1800. удала за трговца, првобрачног Стерију Поповића, старог 38 година (био је придошлица из Земуна, где се претходно водио као Стерио Папаз). Јулијана је знала да чита и пише, а разумевала је и црквенословенски. У овом браку рођено је четворо деце. Јован је рођен 1806. као првенац. Имао је још два брата и сестру. Према натпису на споменику (Idem, одељак с насловом „Споменик који је подигао Ђорђе Стерија Поповић”) који је подигао млађи брат Ј. Стерије Поповића Георгије 1858, њихов отац се након Јулијанине смрти оженио „безчедном” Екатерином. На споменику на вршачком гробљу као деца наведени су синови Павле, Димитрије, „чедни” Јосиф, Антоније и Султана. Даље пише да 33 корака лево према истоку леже кости Јована Стерије Поповића, а да камен с десне стране „означава гроб ћерке Султане”. Натпис закључује Георгијево име, као оног ко подиже споменик „родитељима, браћи” и „својој деци”, што објашњава зашто број деце из Јулијанина два брака није усаглашен са именима из натписа.

7 У брак се ступало рано - девојке већ са 15-16 година, а момци са 17-19. Пунолетство су мушкарци стицали са 24 године. Раније пунолетство мушкарцима је могло бити признато на основу молбе. Бракове су углавном уговарали родитељи или најближи сродници, али, према крају XVIII, постаје све уобичајеније да се пре ступања у брачну заједницу младенци изјасне, односно сагласе са избором брачног друга (ТимотијЕвић 2006: 358-427). О времену за женидбу и дужности мушкарца да буде способан да издржава породицу пре женидбе, што је могло утицати на већу разлику у годинама између супружника и број удовица у грађанском сталежу: Тимотијевић 2006: 367.

${ }^{8}$ С обзиром на то да је преминуо као 36-годишњак, Недељковић је рођен 1759. или 176о. Ступио је у брак са Јулијаном, рођ. Нешковић, највероватније између 1785. и 1790, дакле, могуће после године која се сматра годином Нешковићеве смрти (1785). У браку је рођено двоје деце: Марта (рођ). 1793, умрла 3. јануара 1795, „поживе два лета”) и Павле („крштен 20. октобра 1795.”). Подаци о Недељковићу у Матичној 


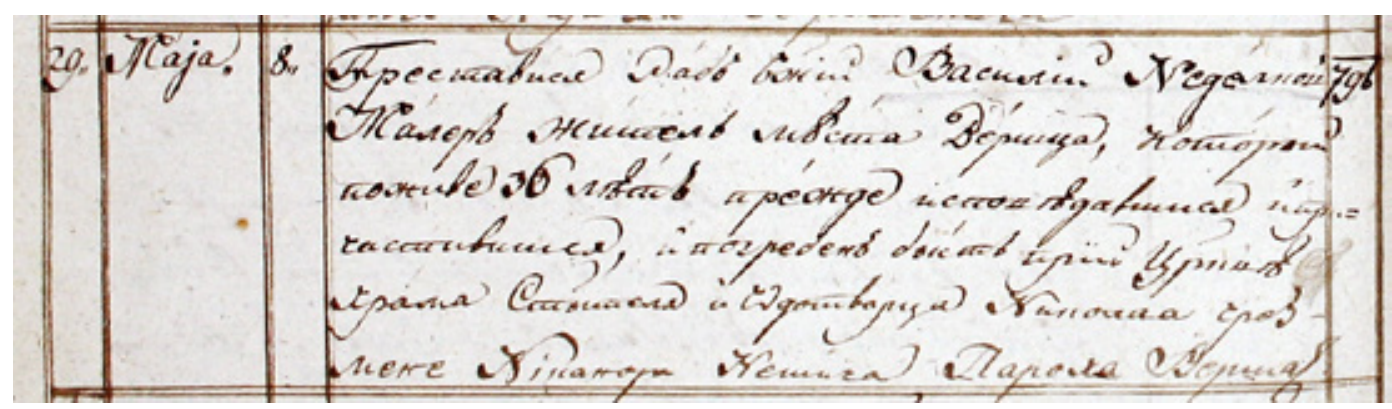

Сл. 3. Датум смрти Василија Недељковића, Књига умрлих Саборне цркве у Вршцу, 29. мај 1796. (фото: Архив Бела Црква)

Сигнатура и датација на Недељковићевој икони Расйеће из Загреба, за коју сада поуздано знамо да је насликао у својим раним тридесетим, налазе се у троредом запису у доњем делу слике десно: „”азъ Васйлї | на льто . 1792: авгұста . 15.” У закључном делу чланка о овој икони Иван Бах (1949: 208) пише:

Nedeljkovićeva je ikona posve barokno koncipirana u duhu Rubensovih i Van Dyckovih kompozicija ovoga motiva, te upravo označava završnu fazu razvitka srpskog slikarstva XVIII. stoljeća. Uz Češljarevo „Mučenje sv. Varvare” vladičanskog dvora u Pakracu može se Nedeljkovićevo djelo ubrojiti među najkarakterističnija djela srpskih majstora XVIII. stoljeća, školovanih u načinu zapadnog slikarstva. Akademski, dijelom maniristički realizam, koji se razvio u srpskoj umjetnosti ovoga razdoblja, bio je temelj daljnjem napretku u prikazivanju stvarnosti, kakav su postigli vojvođanski portretisti 19. stoljeća i time pripravili uspješan razvitak srpskog slikarstva današnjice. (сл. 4).

Када пренебрегнемо идеолошки обојене тонове о неупитном развитку српског сликарства који одражава време цитиране анализе (године обнове и нових почетака након Другог светског рата), стилској оцени Недељковићевог Расӣeћa, као најрепрезентативнијег, и у том моменту јединог познатог рада, тешко да се и из данашње перспективе има шта додати. Ово дело нам показује врсног сликара с краја XVIII века, несумњиво васпитаног на западноевропској традицији, размахнуте кичице и сочног, топлог колорита. Платном доминирају топли тонови црвене, не само због подслика који се провиди кроз ноћно небо него и због употребе неколико нијанси - цинобер огртача Св. Јована Богослова и ружичасте хаљине Марије Магдалене, настале мешањем гримизног пигмента са белом. Палета се још састојала од плаве, окера и смеђе, као и бледољубичасте Богородичине хаљине испод плавог мафориона. Друго

књизи умрлих Успенске цркве у Вршцу пронађени су захваљујући упорности мр Драгојле Живанов, музејског саветника Галерије Матице српске, и помоћи Илије Јовановића, архивисте запосленог у Архиву Беле Цркве. Срдачно захваљујем обома. 
КО ЈЕ НА АУТОПОРТРЕТУ НИКОЛЕ НЕШКОВИЋА: РЕИДЕНТИФИКАЦИЈА АУТОРА , ПИТАҢА...

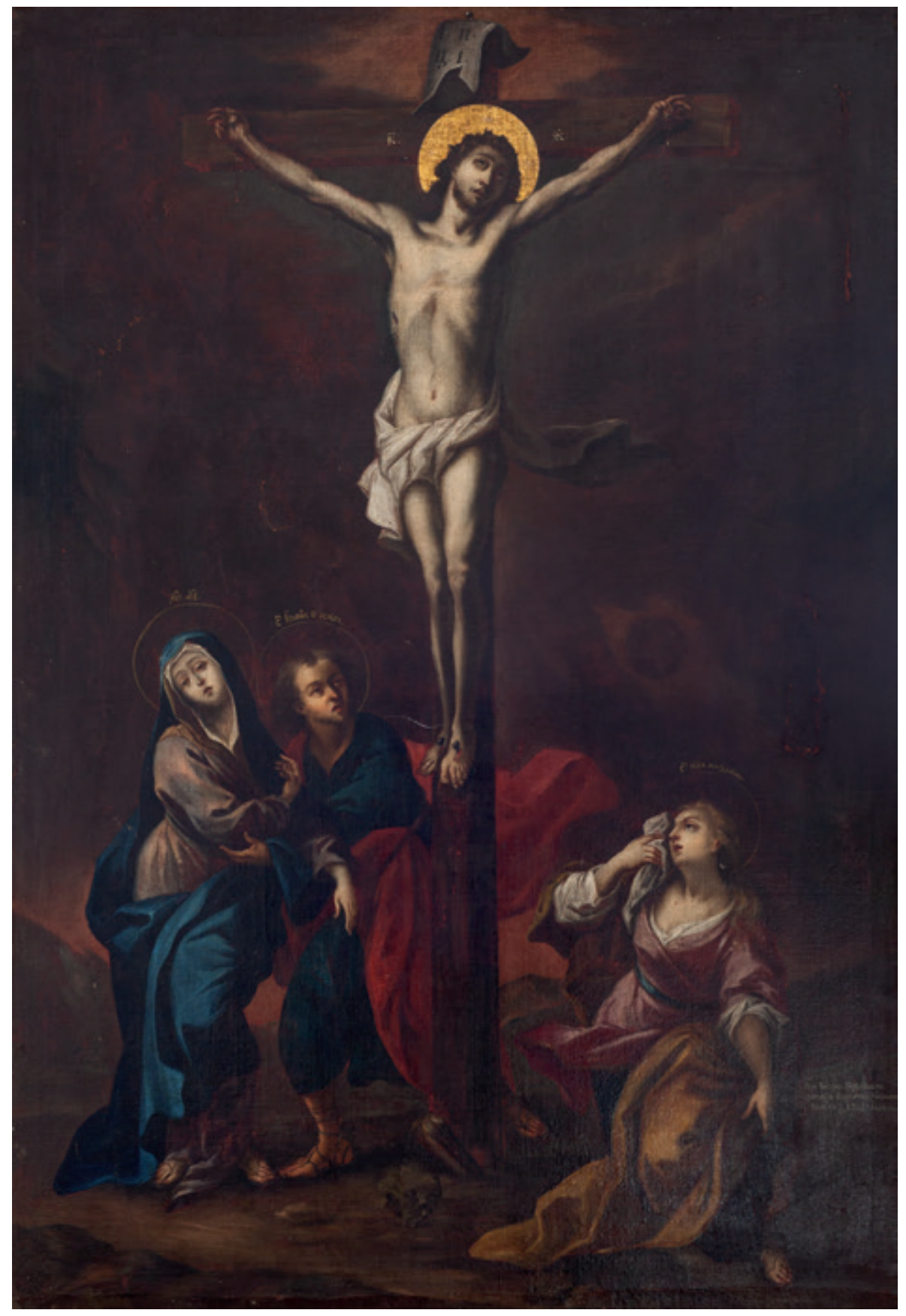

Сл. 4. Pacūeћe, 1792, потписано и датирано, Српска православна црквена општина, Загреб (фото: Маро Мартинић, Загреб) 
Недељковићево потписано дело, икона Боїороgииа са Хрисйом, ако се о томе уопште може судити пре комплетног чишћења, остаје у оквирима сведенијег, али сличног бојеног регистра: Богородичин црвени мафорион, обилато коришћење окера уместо злата. Иако је доста оштећена, ова икона нема карактеристике репрезентативног дела. У време настанка вероватно нека од целивајућих икона у храму, малих димензија $(17,2 \times 13 \mathrm{~cm})$, насликана је на бакарној плочи и још увек је у стилском погледу ближа одликама сликарства тзв. мајстора прелазног периода који тек усвајају тековине барока путем прерађених формула украјинског сликарства. Самим тим, сродна је и сигурним радовима Николе Нешковића, Недељковићевог таста. Вероватна намена ове иконице оправдава примену формуле коју је прихватила верујућа паства. Такви култни предмети не претпостављају размахнутост стила и иконографију која је блиска узорима западног сликарства.

Сликари православне вероисповести, рођени у првој половини XVIII века, тешко су се могли непосредно упознати са стилским решењима западноевропског сликарства, као што сведочи биографија самог Николе Нешковића. ${ }^{9}$ У том смислу драгоцени су подаци који се односе на сликаре католичке вероисповести из будимских сликарских радионица који се, радећи у оквирима еснафских прописа: „oslanjaju na porodičnu radnu snagu, ali su po mogućnosti primani i šegrti i kalfe. Tako je izučavan zanat slikarskog umeća, a tek je druga ili treća generacija budimskih slikara, u drugoj polovini 18. veka, stigla na bečku akademiju.” (Korhecz PAPP 2012: 63). Као штићеник православног владике, по настањењу у Вршцу Нешковић је, по свему судећи, основао радионицу у којој је било више помоћника. Један од њих, вероватно онај који се највише истицао (о чему сведочи благослов за женидбу његовом кћери), могао је бити Василије Недељковић. Недељковић је тако, хипотетички, могао започети бављење сликарством локално, у радионици Николе Нешковића око 1772-1773; потом око 1775. наставити школовање у некој западноевропској радионици (Пожун, Будим, Теми-

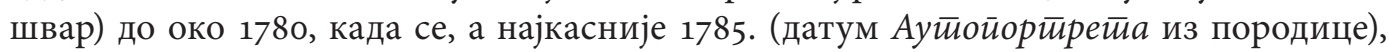
вратио у Вршац, тада започевши (или настављајући) да ради са Нешковићем. У Нешковићевој радионици, као и сличним радионицама широм Хабзбуршке монархије, стварана су дела на којима раде чланови радионице под вођством и по скицама мајстора који њоме руководи. Поред сликања икона и портрета савладавају се и технике позлаћивања и декоративног сликарства (KoRHeCz PAPP 2012: 47), a: „Tek krajem

9 Нешковић је рођен у Пожаревцу, одакле је после слома аустријске управе у Србији пребегао, како се сматра, 1739. Сам је забележио у примерку Жефаровићеве Сйемайоірафбије (чува се у Библиотеци Матице српске) да је у Србији живео до своје десете године, а да се затим обучавао у Карловцима и Петроварадину и „прочим пределима вандровке”. Прихваћено је да је ту учио код Јова Василијевича, а потом је наставио своју сликарску обуку у Пожуну (Братислави), где је, да би био примљен у мајсторску радионицу, морао да се издаје за католика. У Пожуну се срео са потоњим епископом Јованом Георгијевићем који га је по постављењу повео са собом у Вршац, поставши његов главни поручилац и заштитник (Тодић 2013б: 61). Сматра се да је Нешковић уживао заштиту и наредног вршачког епископа, Викентија Поповића. 
18. veka slikari se dele na osnovu dekoraterskih i stvaralačkih poslova, što je već tada zahtevalo akademsku spremu."10 Подлога доњег дела Нешковићеве иконе Светии Бранковићи преко које је исписан опширни запис, изведена је техником декоративног сликарства. ${ }^{11}$ Декоратерске технике познавао је и Василије Недељковић. Да ли их је научио у тастовој радионици, или током школовања у иностранству, може се за сада само нагађати. Архивски подаци о оваквим његовим пословима, међутим, чине за сада најзнатнији део његове биографије (сл. 5). ${ }^{12}$

Даља потрага за могућим Недељковићевим делима усмерила ме је на

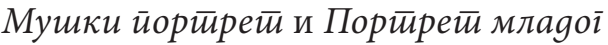
човека, ${ }^{13}$ који су публиковани под упитном атрибуцијом, а пореклом су такође повезани са Нешковићевим наследницима. ${ }^{14} \mathrm{O}$ оба портрета као упитним делима Николе Нешковића

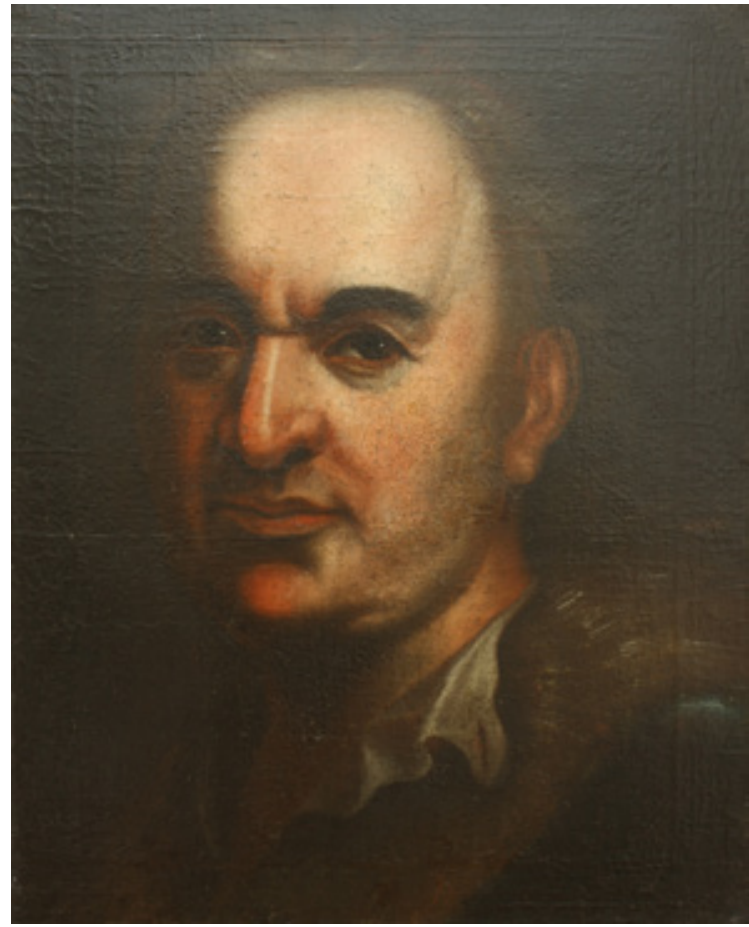

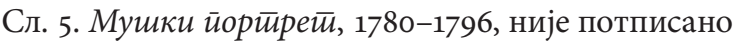
и датирано, Галерија Матице српске (фото:

Галерија Матице српске, Нови Сад)

${ }^{10}$ Из наведеног примера и сведочења Ј. Стерије Поповића о Нешковићевом школовању у Пожуну/Братислави (Поповић 1847: 261), произлази да су сликарске радионице на подручју целе Хабзбуршке монархије функционисале на исти начин. На примеру Стефана Тенецког о овоме пише Тимотијевић 1996: 81-82.

${ }^{11}$ Светии Бранковићи, 1753, Музеј Српске православне цркве, Београд. Поље у дну иконе заузима отприлике петину висине. Подлогу за текст чини трака у виду фриза са плавим ромбовима (цео је само средишњи, лево и десно виде се половине ромба у виду троугла). Подлога је ружичаста, а видљива је као зупчасти низ троуглова око ромбова, горе и доле. Додирне површине између средњеплаве и јаркоружичасте ублажене су тамним окером који замагљује геометризоване ивице. Преко овог поља белом бојом је исписан текст. Икона је једино његово потписано дело и сматра се да представља реплику старије иконе Андреје Раичевића, коју је епископ Јован Георгијевић нашао у манастиру Шемљугу (Тодић 20136: 62)

12 Тодић (2013а: 91) наводи да је Недељковић 1793. обојио врата на сакристији, а 1794. и 1795. позлаћивао јабуке на торњу у Успенској цркви у Вршцу. У Цркви Светог Николе (Саборној) моловао је врата и црквену ограду 1790-1791. године. Године 1794. путовао је у Темишвар ради набавке злата за позлаћивање украса на новосаграђеном торњу. Затим је позлатио два „иконостаса”, а 1795. осликао је и позлатио вазе на фронтону цркве. Фарбарске и позлатарске послове обављао је 1794. године у Богородичиној цркви у Клоподији и у црквама Светог Николе у Ритишеву и Светог Георгија у Војводинцима.

13 Галерија Матице српске, ГМС/У 1316 и 1317.

${ }^{14}$ ШЕЛмИЋ, МилошЕвић и др. 2001: 227, Нешковић, Никола, р. бр. 4 и 5, са ознаком за хипотетичну

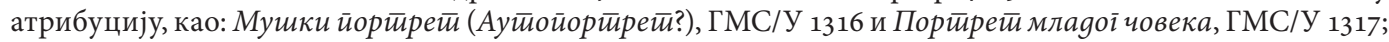




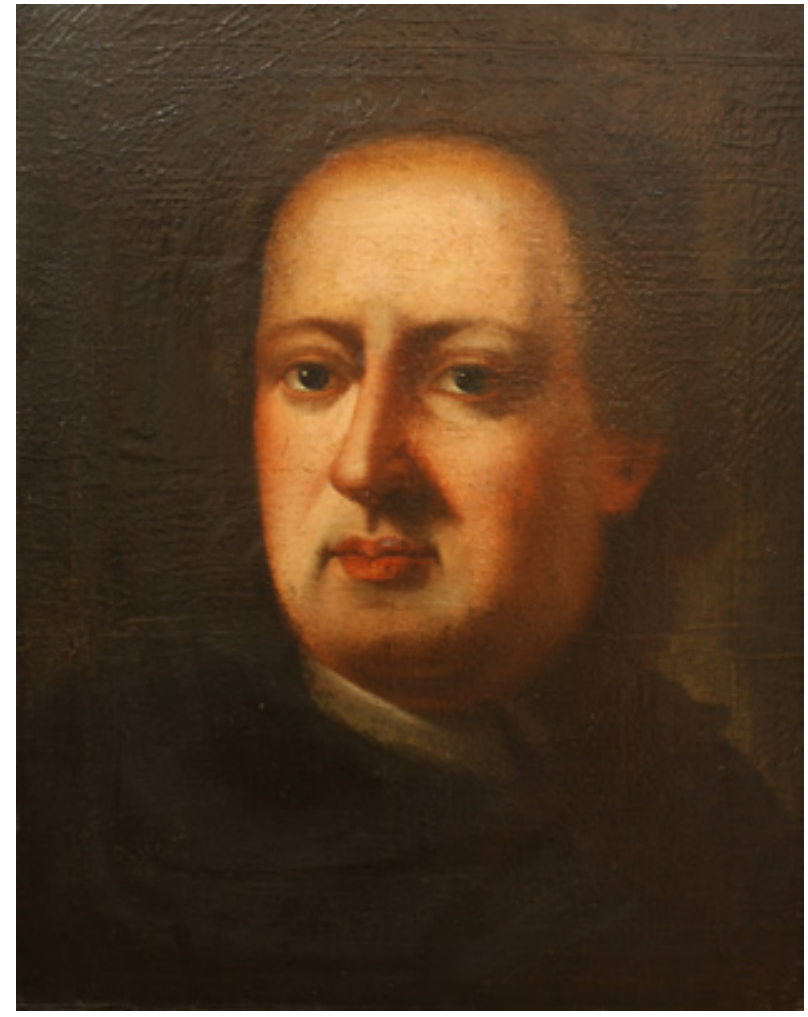

Сл. 6. Поритрети млаgоі човека, 1780-1796, није потписано и датирано, Галерија Матице српске (фото: Галерија Матице српске, Нови Сад)

први је писао Павле Васић (1959: 68-69): „Судећи по типовима, фризури и оделу, ове слике потичу из прве половине XVIII века. Међутим, у општој концепцији ових портрета налазе се елементи стила чешког портретисте Јана Купецког [...], који је уживао велики глас у земљама Средње Европе у XVIII веку.” Васић даље наводи да је Купецки био у Пожуну између 1725 . и 1730, уочавајући да на Мушком

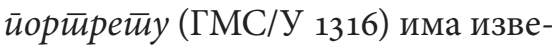
сних детаља који сведоче у прилог могућем Нешковићевом ауторству, износи претпоставку да је можда могуће да се ради о копији аутопортрета мајстора пожунске школе код којег је Нешковић учио. Поредећи овај портрет са Ауйойорӣpe-

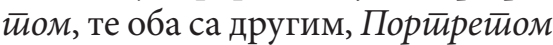
млаgоі човека (ГМС/У 1317), за који каже да га је сликао „мајстор моделације и сфумата”, закључује да је потоњи рад страног мајстора, или да је Нешковић „у пожунској средини под утицајем снажнијих импулса могао да наслика и нешто друкчије од оног [...] у Вршцу."15 (сл. 6).

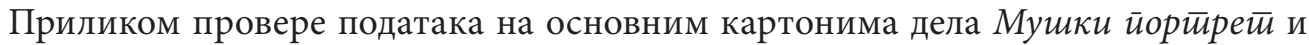

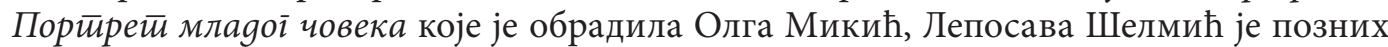
деведесетих година XX века у рубрици напомена прибележила да су оба „могући рад Василија Недељковића". ${ }^{6}$ Већ документација о откупу ових дела илуструје да је атрибуирање Нешковићу било дубиозно:

\footnotetext{
Микит 2003: 166, кат. бр. 127 и 128, објављени као: Нейознатии мущкараи (ГМС/У 1316) и Нейознайи млаgић (ГМС/У 1317), са упитником иза Нешковићевог имена.

${ }^{15}$ Idem.

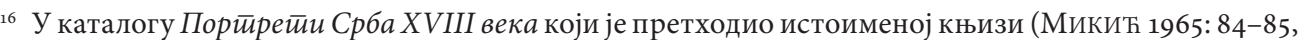

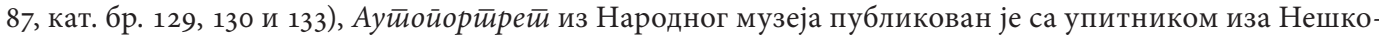
вићевог имена, а два портрета из Галерије Матице српске под неупитном атрибуцијом, с претпоставком

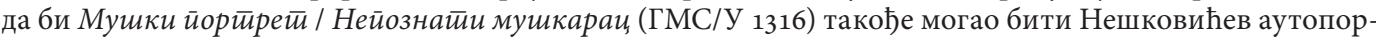
трет.
} 
За понуђене портрете се није могло установити ништа друго сем да су настали у XVIII веку и Комисија је одлучила, уколико се власница са тим слаже, да се исти пошаљу у Савезни институт у Београд на експертизу, где ће се у њиховим лабораторијама вршити испитивања и упоређивања са сигурним Нешковићевим радовима по најновијим методама. Тек по добијеном резултату од њих може доћи до евентуалног откупа. ${ }^{17}$

Да је до „испитивања и упоређивања са сигурним Нешковићевим радовима по најновијим методама” дошло нема трага у сачуваној документацији, али је откуп реализован 1954. године.

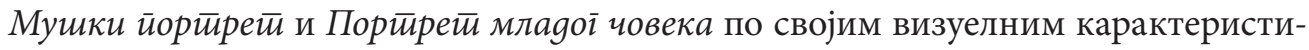
кама - поставци ликова, формату и начину извођења, одступају од типичних портрета XVIII века. Судећи по изражајним физиономским карактеристикама, вероватно је да су представљене конкретне особе. Оба портрета немају уобичајени репрезентативни карактер и пре су налик студијама. Ни један други сачувани портрет из корпуса српске уметности XVIII века, па ни Mлаgu Сава Текелија (који се у последње време приписује сликару Георгију Тенецком $)^{18}$ није кадриран тако смело, тако лишен додатних акцесорија, са главама које испуњавају скоро цео формат платна. Мали формат и генерално камерни, нерепрезентативни приступ при извођењу, какав је мало вероватно да би био примењен да се радило о порученим портретима, сугеришу да су оба могла настати као доказ савладавања вештине, сродно сачуваним портретским студијама наших сликара, школованих током прве половине XIX века у Бечу. ${ }^{19}$ Уколико нису настали према плаћеним моделима, на оваквим портретима неретко су овековечене особе из непосредног окружења, попут чланова породице, или аутора самог. Као такви, они хронолошки могу припадати почецима стварања, када уметник има потребу да се кроз праксу усавршава за будућа поручена дела. Плаузибилност овакве интерпретације потврђују бројни примери светске и домаће историје уметности. У том смислу, проблематичне су оцене Павла Васића и Олге Микић да $M y$ -

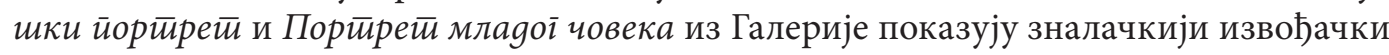
поступак, какав се не очекује од сликара на почетку каријере. ${ }^{20}$ Да ли се, међутим, Стеријин навод да „осим многи(х) његови(х) [Нешковићевих] рукотворина црквени(х),

${ }_{17}$ „Zapisnik sa sastanka Komisije za procenu i otkup umetničkih objekata od 2. VII 1954. - Dodatak”, Стручни архив Галерије Матице српске.

${ }_{18}$ Млаgи Сава Текелија, око 1785, ГМС/У 418. Са овом атрибуцијом и ознаком да је она хипотетична, портрет је први пут објављен у Шелмић, Милошевић и др. 2001: 251, као: Тенецки, Георгије, р. бр. 1. О. Микић га је након овога поново објавила као дело Непознатог сликара у: Микић 20о3: 200,6 р. 195.

19 У Народном музеју у Београду чува се више оваквих студија по природи и копија из треће

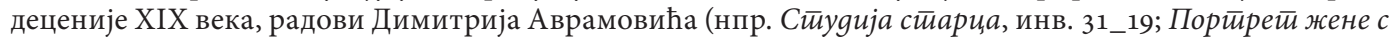
минђушом, инв. 31_6; Глава човека, инв. 31_7о8) и Катарине Ивановић (Глава сйарої обријаної човека, инв. 31_950; Глава човека смеђе браgе, инв. 31_93; Глава човека с gуіом браgом, инв. 31_745).

${ }_{20}$ Усвајајући мишљење Павла Васића да је на оба портрета приметно веће знање од оног које је показао Нешковић, О. Микић износи хипотезу да би они, с обзиром на то да одишу утицајем школе Јана Купецког, ако нису рад самог Нешковића, могли бити рад његовог неидентификованог учитеља из Пожуна. Микић 2003: 78. 
[он] има неколико изображенија”, која, ако су и копије, „отликују се особито танкосћу кичице, а код сваког су художника који их је видео, удивљеније побудиле” (Поповић

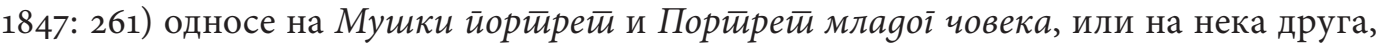
неутврђена, и, могуће, трајно загубљена дела? ${ }^{21}$ Без обзира на одсуство потписа, да ли, такође, постоји неки поуздани ослонац да се ова два портрета, а пре свега Ауйо$\bar{u} о р \bar{u} р е \bar{u}$, сматран делом Николе Нешковића, атрибуирају Василију Недељковићу? Да ли је могуће да је Јован Стерија Поповић, пишући о свом деди (1847: 261), изоставио да напише да је његов лик сачуван на $A y \bar{u} о \bar{u} о р \bar{u} p e \bar{u} y$, а да наводи детаље попут оних да је он шегртујући, издајући се у Пожуну за католика, изазивао љубомору других младића, Немаца који су радили за плату? Зашто непрецизно пише да је Нешковић умро „около године 1786”, када сведочи о детаљима попут оних како је његов деда извршавао тачно оно што је мајстор наложио, а недеље и празнике користио за усавршавање, док су други свој новац трошили на пиће, а Нешковића називали „чивутином"? Да ли би он, његов унук, којем је Нешковићева кћи, његова мајка, дала

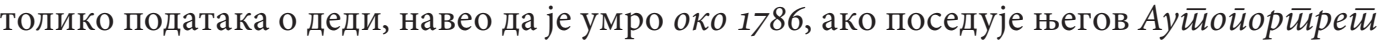
на којем је јасно видљива исписана 1785 . година?

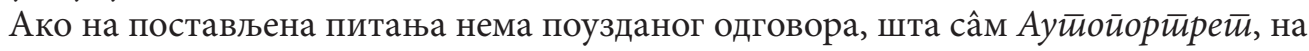
којем је несумњиво представљен његов аутор, одаје? Гледамо у млади лик у трочетвртинском полупрофилу, благо осмехнут, пријатног израза лица, смеђе косе зачешљане уназад, са увојцима косе позади и на левом рамену, сивкастоплавичастих очију испод лучних обрва, које посматрачу радознало узвраћају поглед. Видљиво је десно ухо са фазонираним, уским зулуфом који досеже скоро до ушне ресице. Животност инкарната постигнута је ружичастим тоновима на образима, носу, капцима и у угловима очију. Доњи, светлији део избријаног лика осенчен је испод носа и на бради окерастобраонкастим сенкама. Торзо силуете оцртава се на смеђој позадини отприлике до струка. Десна рука је савијена у лакту, а скупљени прсти грациозно држе танку четкицу. Доњи угао платна десно затвара палета насликана у виду четвртине круга, коју аутор држи делимично видљивом левом руком. Уметник је одевен у тамноплави капутић спуштених рамена, са наглашеним реверима, мало уздигнутим уз врат и са копчањем на дугмад. Испод носи светао гримизни прслук са плитким изрезом око врата и низом крупних, пресвучених дугмади. Сивкасти светлосни

${ }^{21}$ (Савремена графија и обрада текста М. Врбашки). Стерија није за собом оставио директне потомке, већ су дела из породичног власништва, међу којима су поред дела Нешковића могла бити и она Недељковићева, сачувана код сродника. Одговор на питање ко је био један од „художника” код којег су „изображенија” његовог деде (или Василија Недељковића?) „удивленије пробудиле”, мало је лакши. Ради се о сликару Јовану Поповићу, који је свакако видео два мушка портрета (данас у Галерији Матице српске) када је сликао портрете Стерије и његовог брата Георгија (и ове слике су наследили сродници). Блиски однос између Стерије и његовог имењака сликара потврђује податак о кумству. Поповић је насликао чак три Стеријина портрета и један Георгијев. Георгијев и први Стеријин насликани су 1836. у Вршцу: НМ JВ 220/J.В. I 267; НМ JВ 100/J.В. I 268 (ШЕЛМИЋ, КуСОВАЦ и др. 1989: 90, кат. бр. 356 и 358). Преостала два портрета Јована Стерије Поповића сликана су 1849: ГМС/У 412 и НМ инв. 31_1834. УП. КУСОВАЦ 1971: 153, 154, 172, 173. 
рефлекси на наборима прслука сугеришу да је сашивен од свиле или плиша. Врат је обмотан белом марамом од лаке тканине чији крај у виду риша (са деликатним кончаним опшивом који је открио недавни конзерваторско-рестаураторски поступак), пада ка првом закопчаном дугмету на прслуку. Цео портрет одише непретенциозношћу, лежерношћу, уживањем у себи и, истовремено, представи коју аутор креира, далеко од формалности другог аутопортрета у домаћем сликарству XVIII века. Овај аутопортрет, рад Стефана Тенецког, ${ }^{22}$ датиран је око 1770. Нешковић, рођен око 1729, и десетак година старији Тенецки, били су око тридесет до четрдесет година старији од Недељковића. Када би досадашња атрибуција Ауйойорӣретиа Николи Нешковићу била исправна, зар не би приказано по својој појавности требало да буде ближе

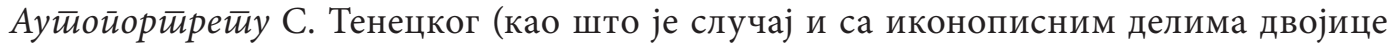
сликара), а не портретима који одишу нежнијим, рокајним расположењима? Зар не би уметник био одевен формалније, у доламу са ширитима у каквима су најчешће приказивани припадници грађанства, његови сународници, током XVIII века, уместо што стилски, по фризури, капутићу и марами подсећа на Доситеја Обрадовића, ${ }^{23}$ онаквог какав је на првом портрету Арсенија Теодоровића из 1794, а који је био основ за Доситејев потоњи визуелни прототип урезан у националну меморију?

Аргумент за атрибуцију Ауйойорӣрейа Василију Недељковићу налази се у кохеренцији уписане године (1785) и онога у шта гледамо. Година није, као што је при-

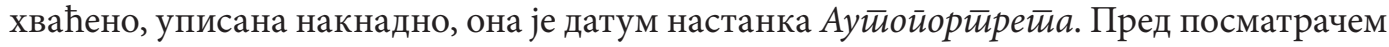
је лик младића у доби од око 25 година (што је сагласно са новопронађеним биографским подацима), истовремено самоувереног и лежерног, приказаног очешљаног и одевеног по актуелној моди. Већ је Вељко Петровић ово угледао, наводећи да: „На том Аутопортрету наш сликар је приказан у помодном оделу XVIII века, à la Goethe, с чипкастом пошом, с љубичастим прсником, с фином кичицом у десној, грациозној руци и с палетом у левој, пред разапетим платном." Портрет тридесетосмогодишњег Гетеа на који Петровић мисли, по свему судећи, рад је Ангелике Кауфман, насликан $1787 .{ }^{24}$ Исте године када је насликан тзв. Ауйойорйрети Николе Нешковића, у ствари вероватни рад Василија Недељковића, Георгије Тенецки, још један сликар нерасветљене биографије, насликао је три портрета за породицу Карамата, житеље Земуна. ${ }^{25}$ Млади Александар Карамата приказан је благо насмешен, баш као и млади Сава Текелија, што се у последње време датира око 1785. и публикује такође као могући рад

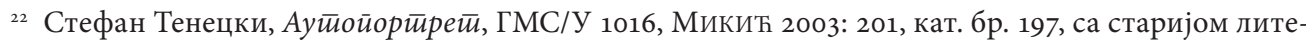
ратуром.

23 За ово запажање и драгоцене консултације везано за мушку моду крајем XVIII века дугујем захвалност мр Катарини Радисављевић, етнологу Музеја Војводине у Новом Саду.

${ }_{24}$ Репродукција портрета на електронској адреси, приступљено 30. IX 2020: https://en.wikipedia. org/wiki/File:Der_junge_Goethe,_gemalt_von_Angelica_Kauffmann_1787.JPG

25 Тодић 2013а: 150. Портрети Димитрија, Марије и Александра Карамате (прив. власништво, Земун) једина су позната дела Георгија Тенецког. Атрибуирани су на основу потписа и иницијала аутора које је уз датацију уписао на полеђини сва три портрета. 


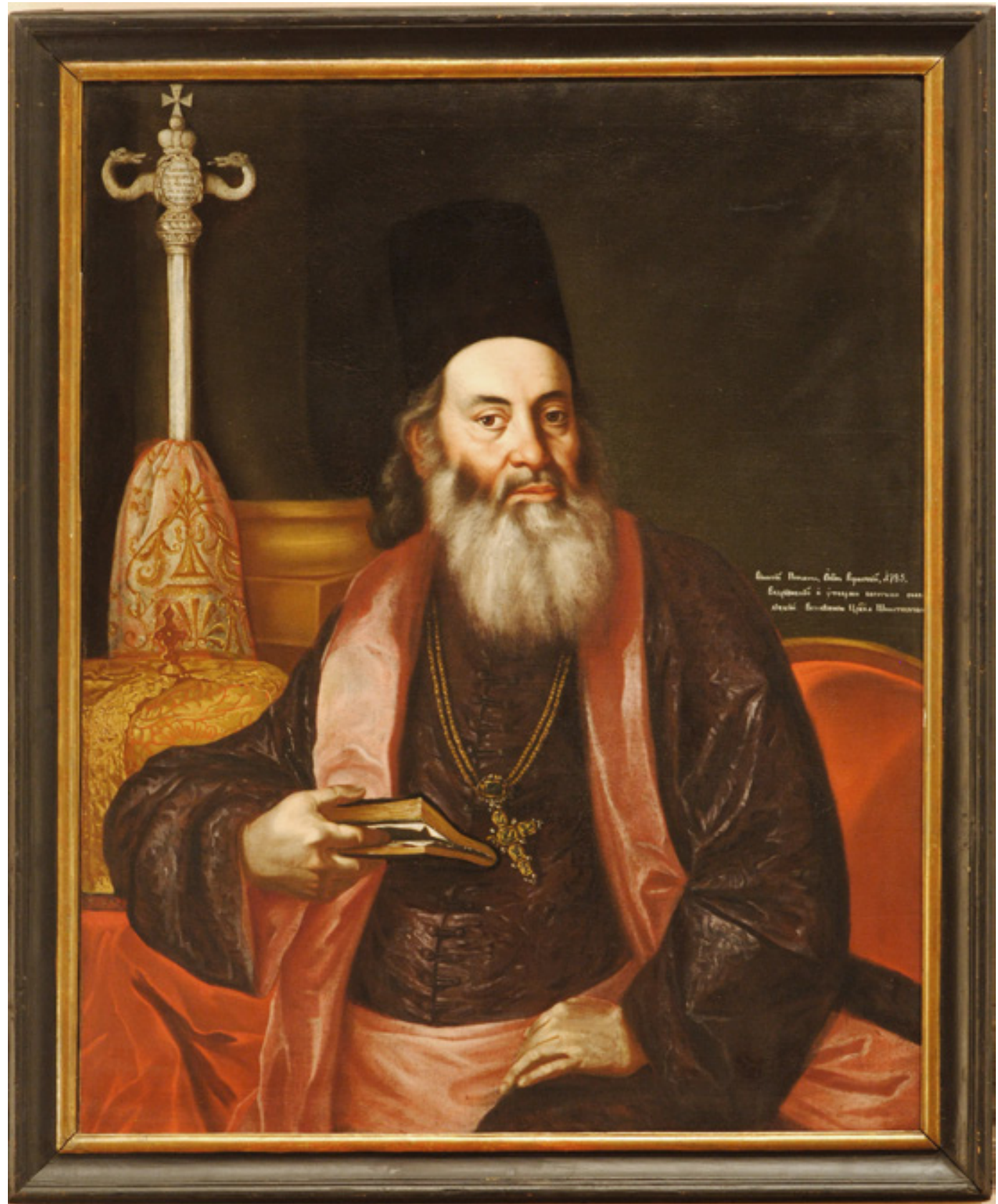

Сл. 7. Викенйије Пойовић, 1785, датирано, није потписано, Музеј Српске православне цркве, Београд (стална поставка Галерије Матице српске; фото: Галерија Матице српске, Нови Сад) 
Георгија Тенецког (Шелмић, Милошевић и др. 2001: 251, Табла 885). Заједничке карактеристике $А y \bar{u} о \bar{u} о р \bar{u} р е \bar{u} а$ и ова два портрета, поред хронологије и сличних година модела, откривају се у тадашњој модерној одећи и изразу портретисаних, који су кохерентни.

Ослонац за предложену промену атрибуције тзв. Нешковићевог аутопортрета, пре него што музејске куће у којима се чувају могући Недељковићеви радови одлуче да их подвргну сложеним и синхронизованим конзерваторским испитивањима, присутан је и у сродној бојеној гами, визуелно конзистентној са сигурним, потписаним Недељковићевим делима. Поткрепљујућа теза за измену атрибуције је и одговарајућа одећа у којој се аутор насликао. Одевање и мода имају веома важну улогу у нашем разумевању фигуративне уметности. Мода се стално мења и одређена одећа изгледа онако како би требало да изгледа само у конкретном времену. Бити обучен „по моди” описује одевање у преовлађујући актуелан костим одређеног времена. Поред чињенице да одевање у модерну одећу конкретизује одређено време, оно уз узраст портретисаног, израз, гест, накит, одликовања и друге акцесорије у позадини представља насликани коิд за статус приказане личности. Сви ови елементи уводе дубље у приказано, подстичући нас да направимо разлику између гледања и виђења, у смислу сагледавања. Уметник бира да ли ће, или неће, приказати особе које слика у модерној одећи, а увиђање ове разлике помаже у откривању значења насликаног. У овом случају, одевање не само да помаже већ постаје помоћни насликани доказ времена

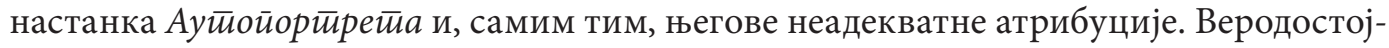
ност костима подржава адекватна датација на самом платну, која није, као што се најпре мислило, а потом понављањем потврђивало, година Нешковићева смрти. ${ }^{26}$ Одећа и година скупа представљају пресуђујући аргумент предложене промене аутор-

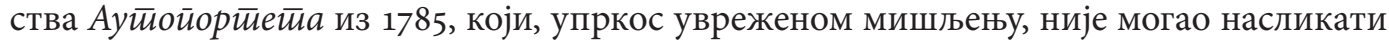
Нешковић, већ Василије Недељковић.

Недељковићева „нова” дела тек је потребно открити (или препознати) међу сачуваним радовима насталим последњих деценија XVIII века. За сада се чини вероватним да његов претпостављени опус броји потписано Расйеће из Загреба, непотписани Мушки

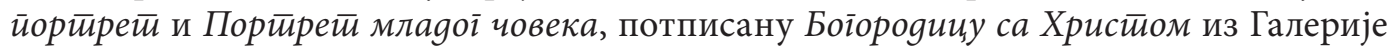

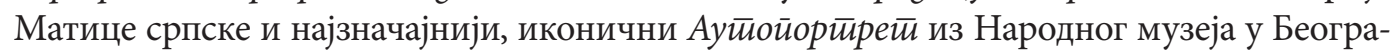
ду. Уколико се поузданије утврди да су предложена дела радови Василија Недељкови-

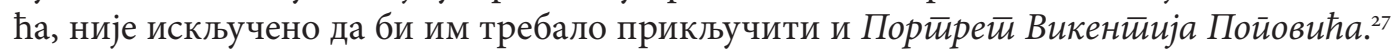

${ }^{26} \mathrm{C}$ обзиром на изнету релативизацију године која је сматрана годином Нешковићеве смрти (1785), потребно је извршити додатни преглед сачуваних Матичних књига из Вршца. Једино тако је могуће утврдити неспорне биографске податке, као и веродостојну годину смрти Николе Нешковића.

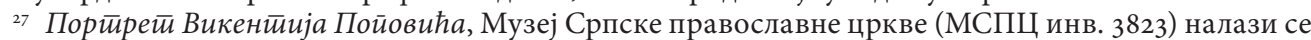
на дугорочној позајмици и излаже се у сталној поставци Галерије Матице српске. Викентије Поповић, рођен у Пожаревцу, вршачки владика, био је заштитник Николе Нешковића. Портрет је пореклом из манастира Шишатовца у којем се Викентије Поповић замонашио, а доцније био његов игуман, архимандрит и добротвор. О портрету Микић 2003: 175-176, кат. бр. 146, са старијом лит. 
Овај портрет, приписан Стефану Гавриловићу, такође је из 1785, насликан је бојама које су карактеристичне за Недељковићеву палету, а његово порекло је могуће довести у везу са Недељковићем.

\section{ЛИТЕРАТУРА}

Аноним. „Стерија и Јулијана Поповић” и „Споменик који је подигао Ђорђе Стерија Поповић” (ANONIM. „Sterija i Julijana Popović” i „Spomenik koji je podigao Đorđe Sterija Popović”). $<$ https://evrsac.rs/ovo-su-znamenite-licnosti-koje-su-sahranjene-na-groblju-u-vrscu/> 14. IX 2020.

BACH, Ivan. „Prilozi povijesti srpskog slikarstva u Hrvatskoj od kraja XVII do kraja XVIII st.” Historijski zbornik II (1949): 185-209.

ВАСит, Павле. „Карактеристике стила Николе Нешковића.” Грађа за йроучаване сйоменика кулйуре (VASIĆ, Pavle. „Karakteristike stila Nikole Neškovića.” Građa za proučavanje spomenika kulture) III (1959): 68-69.

Вујић, Јован. Кайалої Музеја Јоце Вујића у Сенйи. Стручни архив Галерије Матице српске (рукопис, фотокопија) (VUjIĆ, Jovan. Katalog Muzeja Joce Vujića u Senti. Stručni arhiv Galerije Matice srpske (rukopis, fotokopija)).

KOLARIĆ, Miodrag. „Petrović Hristifor.” U: Enciklopedija likovnih umjetnosti. III. Zagreb: Jugoslavenski leksikografski zavod, 1964, 665.

KORHECZ PAPP, Zsuzsanna. Sebastian Stetner pictor Budensis. Subotica: Gradski muzej, 2012.

Кусовац, Никола. Јован Пойовић сликар. Опово: Галерија Јован Поповић (KusovaC, Nikola. Jovan Popović slikar. Opovo: Galerija Jovan Popović), 1971.

КуСовАЦ, Никола. Срйско сликарстиво XVIII и XIX века: Београд: Народни музеј (KusovAC, Nikola. Srpsko slikarstvo XVIII i XIX veka. Beograd: Narodni muzej), 1987.

MEDAKOviĆ, Dejan. „Nedeljković Vasilije.” U: Enciklopedija likovnih umjetnosti. III. Zagreb: Jugoslavenski leksikografski zavod, 1964, 537

Микић, Олга. Поритретии Срба XVIII века. Нови Сад: Галерија Матице српске (МiкIĆ, Olga. Portreti Srba XVIII veka. Novi Sad: Galerija Matice srpske), 1965.

Микић, Олга. Порӣретии Срба XVIII века. Нови Сад: Матица српска (Мікіс́, Olga. Portreti Srba XVIII veka. Novi Sad: Matica srpska), 2003.

ПЕТРОвИЋ, Вељко. „О сликарској уметности Срба у Војводини XVIII и XIX века.” У: КАшАНИН,

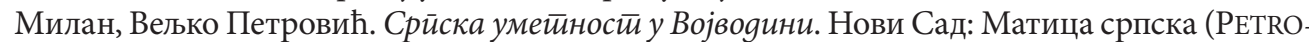
VIĆ, Veljko. „O slikarskoj umetnosti Srba u Vojvodini XVIII i XIX veka.” U: KAŠANIN, Milan, Veljko Petrović. Srpska umetnost u Vojvodini. Novi Sad: Matica srpska), 1927, 63-135.

Поповић, Јован Стерија. „Одломакъ пъсмє єдне одъ године 1776.” и „Примътба.” Гласник Друшимва срйске словесностии (Popović, Jovan Sterija. „Odlomakъ рЂsmє €dne odъ godine 1776.” i „PrimŁtba.” Glasnik Društva srpske slovesnosti) I (1847): 258-261, 259-261. <http:// digital.bms.rs/ebiblioteka/pageFlip/reader/index.php?type $=$ numerated $\&$ id $=5375 \& \mathrm{~m}=2 \#$ page/ 7/mode/1up > 9. X 2020.

Тимотијевит, Мирослав. Срйско барокно сликарсииво. Нови Сад: Матица српска (ТімотіјЕVIĆ, Miroslav. Srpsko barokno slikarstvo. Novi Sad: Matica srpska), 1996. 


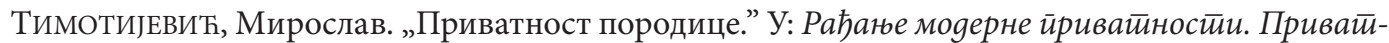
ни животи Срба у Хабзбуршкој монархији оg краја 17. gо йочет̄ка 19. века. Београд: Clio (Timotijević, Miroslav. „Privatnost porodice.” U: Rađanje moderne privatnosti. Privatni život Srba u Habzburškoj monarhiji od kraja 17. do početka 19. veka. Beograd: Clio), 2006, 358-427.

Тодић, Бранислав. „Василије Недељковић.” и „Георгије Тенецки.” У: Срйски сликари og XIV go XVIII века. Петроварадин - Нови Сад: Покрајински завод за заштиту споменика Платонеум (ToDIĆ, Branislav. „Vasilije Nedeljković.” i „Georgije Tenecki.” U: Srpski slikari od XIV do XVIII veka. Petrovaradin - Novi Sad: Pokrajinski zavod za zaštitu spomenika Platoneum), 2013a, 91, 150.

Тодић, Бранислав. „Никола Нешковић.” У: Срӣски сликари og XIV go XVIII века. Петроварадин - Нови Сад: Покрајински завод за заштиту споменика - Платонеум (ToDIĆ, Branislav. „Nikola Nešković.” U: Srpski slikari od XIV do XVIII veka. Petrovaradin - Novi Sad: Pokrajinski zavod za zaštitu spomenika - Platoneum), 20136, 61-68.

Филиповић, Даница, Никола Марковић. Јоца Вујић велики gобройвор Беоі̄раgскоі универзи-

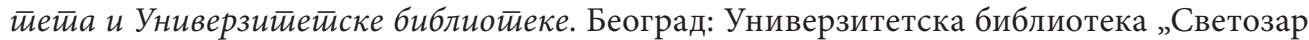
Марковић” (FILIPOviĆ, Danica, Nikola Marković. Joca Vujić veliki dobrotvor Beogradskog univerziteta i Univerzitetske biblioteke. Beograd: Univerzitetska biblioteka „Svetozar Marković”), 2012. <http://www.arhiva.unilib.rs/unilib/o_nama/izlozbe/joca-vujic/joca-vujic-katalog.pdf> 21. IX 2020.

Шелмић, Лепосава, Никола Кусовац, Љубица Миљковић, Татјана Бошњак, Драгојла Жива-

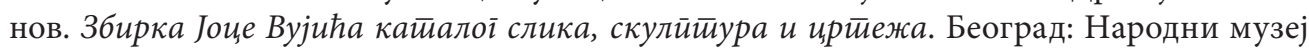
(ŠELMiĆ, Leposava, Nikola Kusovac, Ljubica Miljković, Tatjana Bošnjak, Dragojla Živanov. Zbirka Joce Vujića katalog slika, skulptura i crteža. Beograd: Narodni muzej), 1989.

Шелмић, Лепосава, Емица Милошевић, Драгојла Живанов, Милена Врбашки, Сузана Вуксановић Солеша, Јован Тепавчевић, Добрила Јерков, Борислав Радановић. Галерија Майице срӣске. Нови Сад: Галерија Матице српске (ŠElmić, Leposava, Emica Milošević, Dragojla Živanov, Milena Vrbaški, Suzana Vuksanović Soleša, Jovan Tepavčević, Dobrila Jerkov, Borislav Radanović. Galerija Matice srpske. Novi Sad: Galerija Matice srpske), 2001.

\author{
Milena G. Vrbaški \\ WHO IS ON NIKOLA NEŠKOVIĆ'S SELF-PORTRAIT - \\ AUTHOR'S REIDENTIFICATION, QUESTIONS, AND SOME ANSWERS
}

\title{
Summary
}

The iconic work whose attribution is discussed in this paper was introduced into Serbian art history as the Self-Portrait of Nikola Nešković (c.1729 - c.1785) in the book Srpska umetnost $u$ Vojvodini (Serbian Art in Vojvodina) in 1927. Although the Self-Portrait has been published several times over the past 93 years with questionable attribution, no effort has been made to refute the thesis of Nešković's authorship. The starting point for finding a more probable author was the discovery of another signed painting by an almost completely unknown painter, Vasilije Nedeljković (1759 or 1760-1796), who was related to Nikola Nešković (Nešković's son-in-law, married to his 
daughter Julijana). Only Nedeljkovićs Crucifixion (Zagreb, Serbian Orthodox Church Municipality, 1792) was previously known, whose artistic achievements were highly valued. Finding a more probable candidate for the authorship of the Self-Portrait made it possible that what was shown and what was known about the work can be presented in a new way. The dating recorded on the SelfPortrait (1785) is considered as the date of the work's creation and is not connected with the year of Neškovićs death, which, according to previous undivided interpretations, referred to the subsequently entered year of Neškovićs death. The artistic values of the Self-Portrait and signed works provided the basis for a different interpretation of several unsigned works that have the same origin, or can otherwise be included in Nedeljković's hypothetical/lost opus. In addition to the hypotheses, reliable information about the previously unknown date of Nedeljkovićs death is also given, which represents a reference point for a possible artist's biography. Attention was also drawn to the need for further research to obtain more reliable data, both on Vasilije Nedeljković and Nikola Nešković.

Keywords: Self-Portrait of Nikola Nešković, Vasilije Nedeljković, reidentification of the author of the Self-Portrait, reinterpretation of the meaning of dating on the Self-Portrait (1785), coherence of the presentation and date as a visual basis for the re-attribution of the Self-Portrait. 